\title{
A new genus of the tribe Ceutorhynchini (Coleoptera: Curculionidae) in Baltic amber
}

\author{
Andrei A. Legalov \& Andris Bukejs
}

Legalov, A. A. \& Bukejs, A. 2018: A new genus of the tribe Ceutorhynchini (Coleoptera: Curculionidae) in Baltic amber. — Entomol. Fennica 29: 185-190.

A new genus, Baltocoeliodes gen. n. (type species: B. sontagae sp. n.) is described and illustrated from Eocene Baltic amber. Baltocoeliodes is close to Coeliodinus Dieckmann, 1972 but differs by having the femora with a large tooth, robust elytra, and elytral intervals with rasp-like granules. It differs from the genus Brevicoeliodes Korotyaev, 1997 by the short apical comb of setae on the protibiae, the long and curved rostrum, femora with a large tooth, and elytral intervals with rasp-like granules.

A. A. Legalov, Institute of Systematics and Ecology of Animals, Siberian Branch, Russian Academy of Sciences, Frunze Street, 11, Novosibirsk 630091, Russia and Altai State University, Lenina, 61, Barnaul 656049, Russia; Corresponding author's e-mail:fossilweevils@gmail.com

A. Bukejs, Institute of Life Sciences and Technologies, Daugavpils University, Vienības 13, Daugavpils,LV-5401,Latvia; e-mail: carabidae@inbox.lv

Received 10 March 2018, accepted 14 April 2018

\section{Introduction}

Weevils of the subfamily Conoderinae include more than 7,500 species placed in four supertribes in the Recent fauna (Prena et al. 2014). Previously, these four supertribes were treated as different subfamilies (Alonso-Zarazaga \& Lyal 1999, Anderson 2002, Bouchard et al. 2011), but only one subfamily is accepted now (Prena et al. 2014). The six earliest known fossil species of Conoderinae of the supertribes Ceutorhynchitae and Bariditae have been described from the earlymiddle Eocene Green River Formation (Scudder 1893, Legalov 2015). Three species of the genus Ceutorhynchus Germar, 1823 (Ceutorhynchini) have been described (Legalov 2013, 2016) and one species of the genus Rhinoncus Schoenherr, 1825 (Phytobiini) has been recorded from middle-upper Eocene Baltic amber (Klebs 1910). The most ancient Conoderitae known are from
Early-Middle Miocene Dominican and Mexican amber (Zimmermann 1971, Davis \& Engel 2006, Poinar \& Legalov 2014). A species of the tribe Phytobiini is known from the Oligocene of Germany (Théobald 1937), and another of the tribe Cnemogonini from the late Eocene of Florissant (Scudder 1893). A few Ceutorhynchini species have been described from the Eocene of Florissant (Scudder 1893, Wickham 1916), Oligocene of France (Förster 1891) and Germany (Heyden \& Heyden 1866), and also the Neogene of France (Piton \& Théobald 1935).

In the present paper, a new genus and species of the tribe Ceutorhynchini are described from Baltic amber.

\section{Materials and methods}

The amber piece from Kaliningrad region, Russia was polished by hand, allowing an improved 
view of the included specimen, and was not subjected to any supplemental fixation. The material examined is deposited in the collection of the $\mathrm{Mu}-$ seum of Amber Inclusions, University of Gdańsk, Poland [MAIG].

The observations of the specimen were made using a Nikon SMZ 745T stereomicroscope. The photographs were taken using a camera Canon $70 \mathrm{D}$ with macrolens Canon MPE-65mm. Extended depth of field at high magnifications was achieved by combining multiple images from a range of focal planes using Helicon Focus software. Measurements in millimeters were taken using an ocular micrometer.

The systematic placement of the studied taxon is according to Prena at al. (2014) and Colonnelli (2004).

\section{Description of Baltocoeliodes gen. $\mathbf{n}$. and $B$. sontagae sp. $n$.}

Curculionidae Latreille, 1802

Conoderinae Schoenherr, 1833

Ceutorhynchitae Gistel, 1848

Ceutorhynchini Gistel, 1848

\section{Baltocoeliodes gen. $\mathbf{n}$.}

Type species: Baltocoeliodes sontagae sp. n., described below.

Diagnosis. This new genus is close to the extant genus Coeliodinus Dieckmann, 1972 but differs in the femora possessing a large ventral tooth, robust elytra, and elytral intervals with denticulate granules. Additionally, Baltocoeliodes gen. n. differs from the genus Brevicoeliodes Korotyaev, 1997 by the short apical comb of setae on the protibiae, long rostrum, femora with a large ventral tooth, and elytral intervals with denticulate granules.

Etymology. The name is formed from the Latin word for "Baltic" - "balticum" and the generic name "Coeliodes". The gender is masculine.

Note. The new genus is monotypic, represented by the type species only. Therefore, the generic description considerably overlaps that of the species.
Description of Baltocoeliodes sontagae sp. $n$. (Figs 1, 2)

Type material. Holotype: Nr. 5952 [MAIG]; possibly male. A complete beetle is included in an elongate, transparent yellow amber piece (length $35 \mathrm{~mm}$, width $17 \mathrm{~mm}$, and maximum thickness 8 $\mathrm{mm}$ ). Syninclusions: plant leaf (length about 25 $\mathrm{mm}$ ), few small pieces of organic material, numerous small stellate Fagaceae trichomes, and small gas vesicles.

Type locality and type strata. Amber deposits located along the Baltic Sea coast, Yantarny settlement [formerly Palmnicken], Kaliningrad region, Russia; mid-Eocene to Upper Eocene.

Description. Body length (without rostrum and head) $2.5 \mathrm{~mm}$, maximum width $1.7 \mathrm{~mm}$; body shape widely oval; body colour (as preserved) rufous with head and pronotum slightly darker, reddish-brown. Pronotum sparsely covered with short, stout erect filiform scales with curved apices; elytra with short semirecumbent scales; head, ventral side of body and legs with dense, short recumbent scales.

Head. Hypognathous, with fine and dense punctation. Rostrum weakly curved, longer than head and pronotum combined, reaching apical margin of metaventrite; eyes large, rounded, weakly convex; temples short; antennae geniculate, inserted apparently near middle of rostrum laterally; antennae quite long (poorly visible in examined specimen), antennomere 1 long, not extending to eyes; antennomeres 2-8 subconical; antennomere 2 about 2.2 times as long as wide, nearly equal in width to antennomere 1 ; antennomere 3 about 2.5 times as long as wide, 0.5 times as long as and 0.4 times as wide as antennomere 2; club compact with fused articles.

Pronotum. Bell-shaped, widest before middle, distinctly narrower than elytral base, convex; transverse, about 1.6 times as wide as long; densely covered with large punctures, distance between punctures less than diameter of one puncture, interspaces convex, shiny; with shallow longitudinal impression medially, without lateral tubercles; anterior margin almost straight in dorsal view; posterior margin bi-sinuate with two teeth medially (at scutellum); lateral margins widely rounded. Scutellum elongate, narrow, small, about 2.5 times as long as wide. 


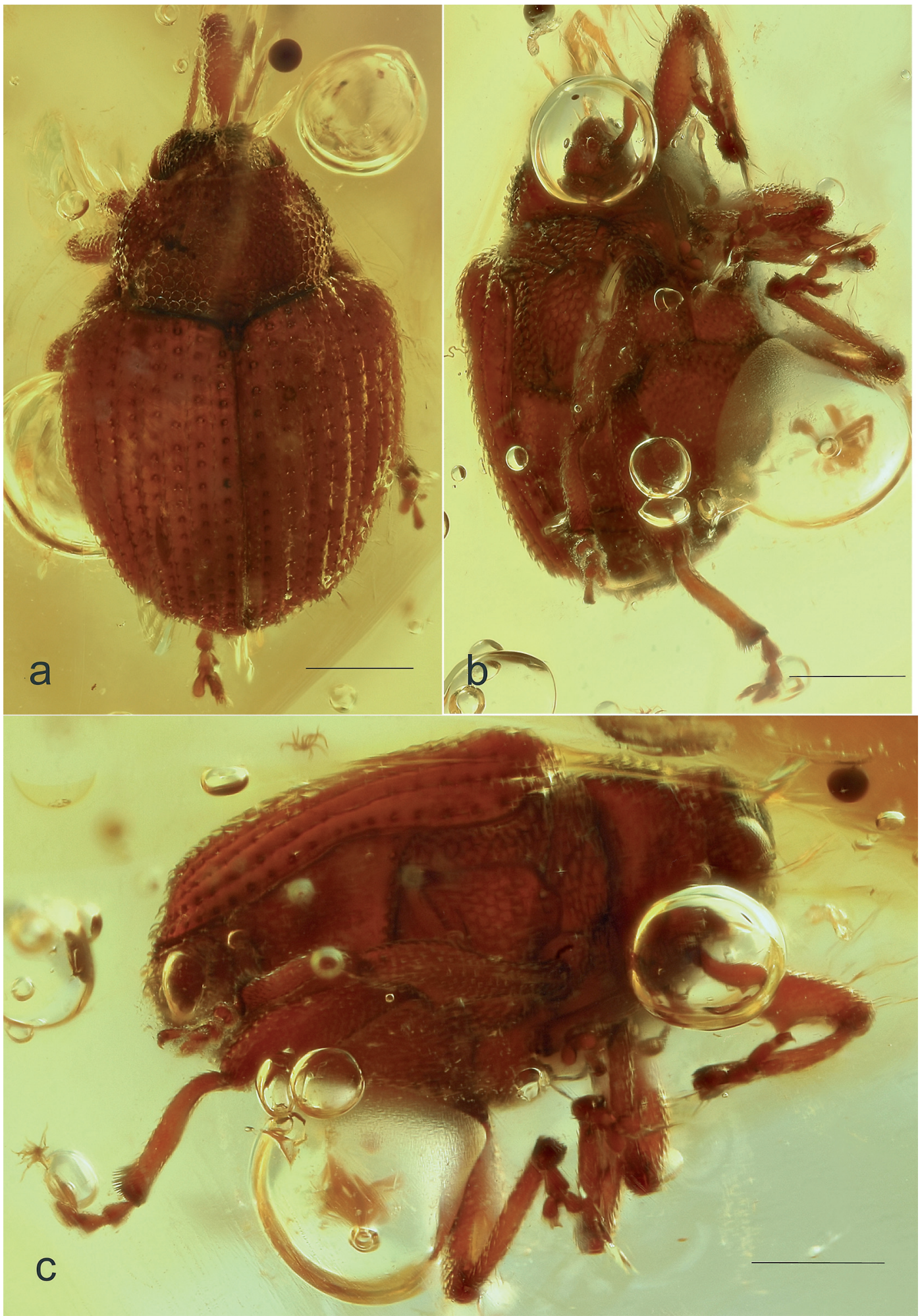

Fig. 1. Baltocoeliodes sontagae gen. n. et sp. n., habitus of holotype. - a. Dorsal view. - b. Ventro-lateral view. - c. Lateral view. Scale bar $0.5 \mathrm{~mm}$. 


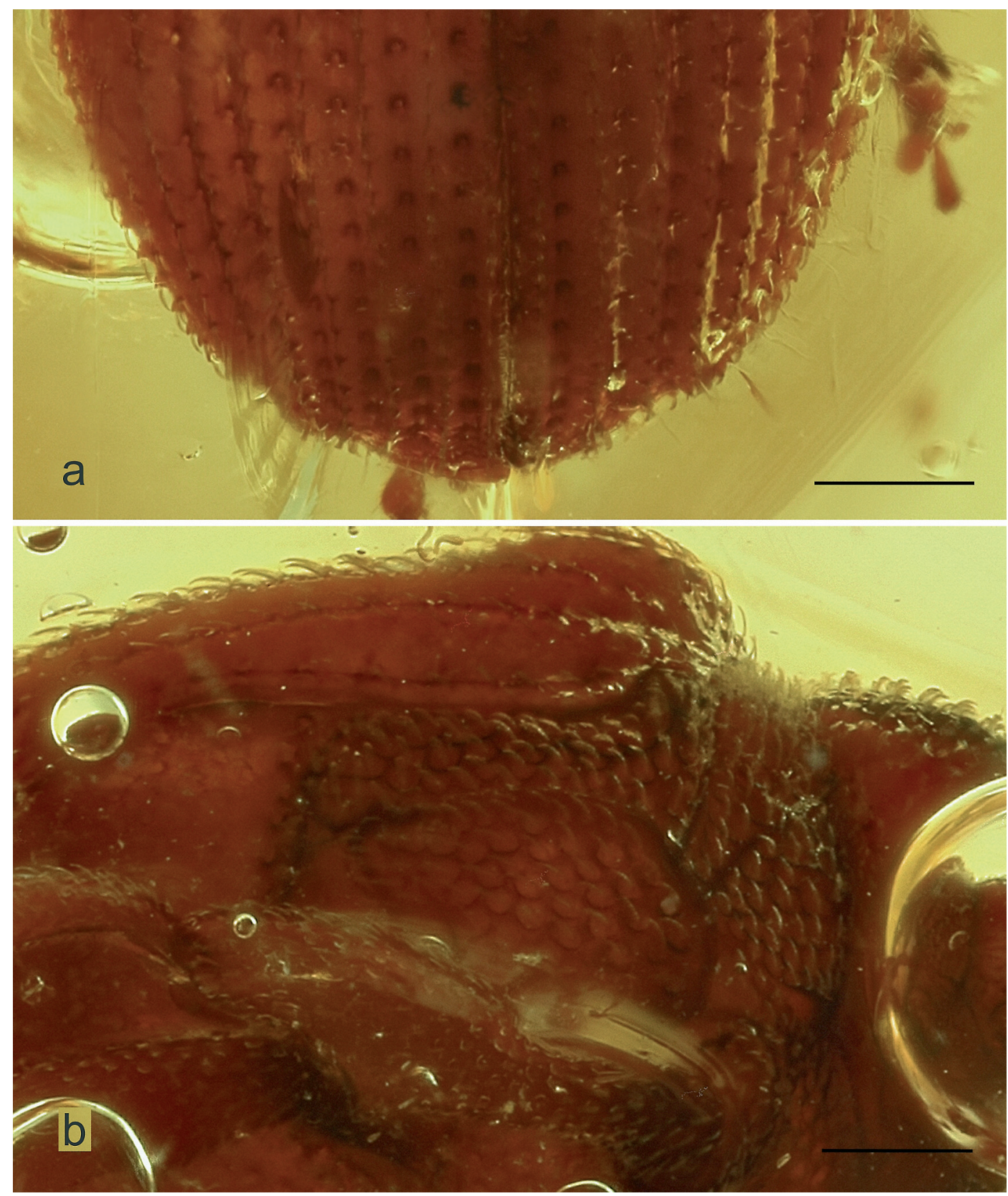

Fig. 2. Baltocoeliodes sontagae gen. $\mathbf{n}$. et sp. $\mathbf{n}$., details of holotype. - a. Elytral apical portion, dorsal view. - b. Thorax, lateral view. Scale bar $0.25 \mathrm{~mm}$.

Elytra. Widely oval, nearly as long as wide at base, 2.3 times as long as pronotum; humeri weakly rounded, protruding. Elytral punctures small, round, sparse (distinctly denser in apical portion), distance between strial punctures equal to 1.5-2.5 times diameter of one puncture; arranged in regular striae, each elytron with 10 striae, striae distinct throughout entire length of elytron, stria 10 complete; interstrial intervals shiny, convex, with small denticles (distinctly visible in apical half), arranged in regular row, distance between striae about 2.0-4.0 times diameter of one strial puncture; with denticulate granules. 
Thorax. Pro-, meso- and metathorax coarsely and densely punctate, distance between punctures less than diameter of one puncture. Prosternum apparently with ventral channel; precoxal part of prosternum quite long; postcoxal part of prosternum short, procoxal cavities separated; mesepimeron enlarged, visible between bases of prosternum and elytra, mesosternum with ventral channel; metasternum quite long, about 1.9 times as long as length of metacoxa, metepisternum about 3.0 times as long as wide, metepimeron fused with metepisternum.

Legs. Long and quite robust; procoxae conical, mesococae round, metacoxae transverse; femora weakly swollen, spindle-shaped, with large ventral tooth; tibiae weakly curved, dilated apically, without uncus and mucro; protibia with apical comb of setae extending along external margin for distance about one-fifth of tibial length; mesotibia with apical comb of setae extending along external margin for distance about one-fouth of tibial length; metatibia with apical comb of setae extending along external margin for distance about one-sixth of tibial length; tarsi long, apparently with thick light erect setae dorsally, with two claws, tarsomeres 1 and 2 trapezoidal, tarsomere 3 bilobed, tarsomere 4 minute, tarsomere 5 elongate; claws large, fused at base, with teeth.

Abdomen. Slightly convex, with small and dense punctation, distance between punctures equal to $0.8-1.2 \times$ diameter of one puncture; all ventrites oriented in one plane; ventrites 1 and 2 fused; posterior angles of ventrites 2-4 extended towards ventrites $3-5$; ventrite 1 about as long as width of metacoxa; ventrite 2 about 0.4 times as long as ventrite 1 medially; ventrites 3 and 4 subequal in length; ventrite 3 about 0.5 times as long as ventrite 2 ; pygidium convex, not covered by elytra.

Etymology. Patronymic. The name of this new species is dedicated to our colleague Dr. Elżbieta Sontag (Gdańsk, Poland), who provided us the opportunity to study this interesting fossil specimen.

Remarks. The new species belongs to the family Curculionidae based on the geniculate antennae, ventrites 1 and 2 being fused and elongate, ventrites 3 and 4 short, and ventrites $1-5$ oriented in one plane. The enlarged mesepimeron being visible between the bases of the prosternum and elytra, the posterior angle of ventrite 2 extending towards ventrite 3 , and the metepimeron being fused with metepisternum, suggest placement in the subfamily Conoderinae. The tibiae being without an uncus, pygydium not covered by elytra, and prosternum with a ventral channel allow this taxon to belong to Ceutorhynchitae. The tarsi having two claws, metafemora being weakly swollen, and elongate rostrum confirm the assignment of Baltocoeliodes sontagae gen. n. et sp. n. to the tribe Ceutorhynchini.

Acknowledgements. We are sincerely grateful to Elżbieta Sontag (Museum of Amber Inclusions, University of Gdańsk, Poland) for the loan of amber material, to Mr. Jonas Damzen (Vilnius, Lithuania) for permission to use his photographs, to Boris A. Korotyaev (St.-Petersburg, Russia) for the opportunity to study comparative material, and to Enzo Colonnelli (Roma, Italy) for reading and correcting an early version of the manuscript. We thank two anonymous reviewers for valuable suggestions that improved the manuscript.

\section{References}

Alonso-Zarazaga, M. A. \& Lyal, C. H. C. 1999: A world catalogue of families and genera Curculionoidea (Insecta: Coleoptera) (excepting Scolytidae and Platypodidae). - Entomopraxis, Barcelona, 316 p.

Anderson, R. S. 2002: Curculionidae Latreille 1802. - In: Arnett, R. H.† Jr., Thomas, M. C., Skelley, P. E. \& Frank, J. H. (eds), American beetles, Volume 2. Polyphaga: Scarabaeoidea through Curculionoidea: 722-815. CRC Press, Boca Raton-London-New York-Washington. 861 pp. + xiv.

Bouchard, P., Bousquet, Y., Davies, A. E., Alonso-Zarazaga, M. A., Lawrence, J. F., Lyal, C. H. C., Newton, A. F., Reid, C. A. M., Schmitt, M., Ślipiński, S. A. \& Smith, A. B. T. 2011: Family group names in Coleoptera (Insecta). - Zookeys 88: 1-972.

Colonnelli, E. 2004: Catalogue of Ceutorhynchinae (Insecta: Coleoptera: Curculionidae) of the world, with a key to genera. - Argania editio, Barcelona. 124 pp.

Davis, S. R. \& Engel, M. S. 2006: A Zygopine weevil in Early Miocene amber from the Dominican Republic (Coleoptera: Curculionidae). - Caribbean Journal of Science 42(2): 255-257.

Förster, B. 1891: Die Insekten des "Plattigen Steinmergels" von Brunstatt. Mit secht Tafeln im Lichtdruck Abhandlungen der Geologischen Specialkarte von Elsass-Lotheringen 3(5): 333-594 + pls. XI-XVI. [In German.]

Heyden, C. \& Heyden, L. 1866: Käfer und Polypen aus der Braunkohle des Siebengebirges. Taf. XXII-XXIV. - 
Palaeontographica 15: 131-156 + pls. XXII-XXIV. [In German.]

Klebs, R., 1910: Über Bernsteinschlüsse im allgemein und die Coleopteren meiner Bernsteinsammlung. Schriften der Physikalisch-Ökonomischen Gesellschaft zu Königsberg im Prussia 51(3): 217-242. [In German.]

Legalov, A. A. 2013: New and little known weevils (Coleoptera: Curculionoidea) from the Paleogene and Neogene. - Historical Biology 25(1): 59-80.

Legalov, A. A. 2015: Fossil Mesozoic and Cenozoic weevils (Coleoptera, Obrienioidea, Curculionoidea). Paleontological Journal 49(13): 1442-1513.

Legalov, A. A. 2016: New weevils (Curculionidae) in Baltic amber. — Paleontological Journal 50(9): 970-985.

Piton, L. \& Théobald, N. 1935: La faune entomologique des gisements miopliocčnes du Massif Central. - Revue des Sciences Naturelles d' Auvergne 2, 1-81. [In French.]

Poinar, G. Jr. \& Legalov, A. A. 2014: New species of the subfamily Conoderinae (Coleoptera: Curculionidae) in Dominican amber. - Historical Biology 26(5): 556-562.
Prena, J., Colonnelli, E. \& Hespenheide, H. A. 2014: 3.7. 9. Conoderinae. - In: Leschen, R. A. B. \& Beutel, R. G. (eds), Handbook of Zoology. Arthropoda: Insecta. Tb. 40: Coleoptera (Beetles). Volume 3: Morphology and Systematics (Phytophaga): 577-589. De Gruyter, Berlin and Boston. 675 pp.

Scudder, S. H. 1893: Tertiary Rhynchophorus Coleoptera of the United States. - Monographs of the United States Geological Survey. Volume XXI. Government Printing Office, Washington, $\mathrm{xi}+206$ p. +12 pls.

Théobald, N. 1937: Les insectes fossiles des terrains oligocčnes de France. - Bulletin mensuel de la Société des sciences de Nancy 1: 1-473. [In French.]

Wickham, H. F. 1916: New fossil Coleoptera from the Florissant beds. - Bulletin from the Laboratories of Natural History, Iowa 7(3): 3-19, I-IV.

Zimmermann, E. C. 1971: Mexican Miocene amber weevils (Insecta: Coleoptera: Curculionidae). - University of California Publications in Entomology 63(2): 103-106. 